\title{
Breaking the Silence
}

A volume in the series Anthropology of Contemporary Issues EDITED BY ROGER SANJEK

A full list of titles in the series appears at the end of the book. 


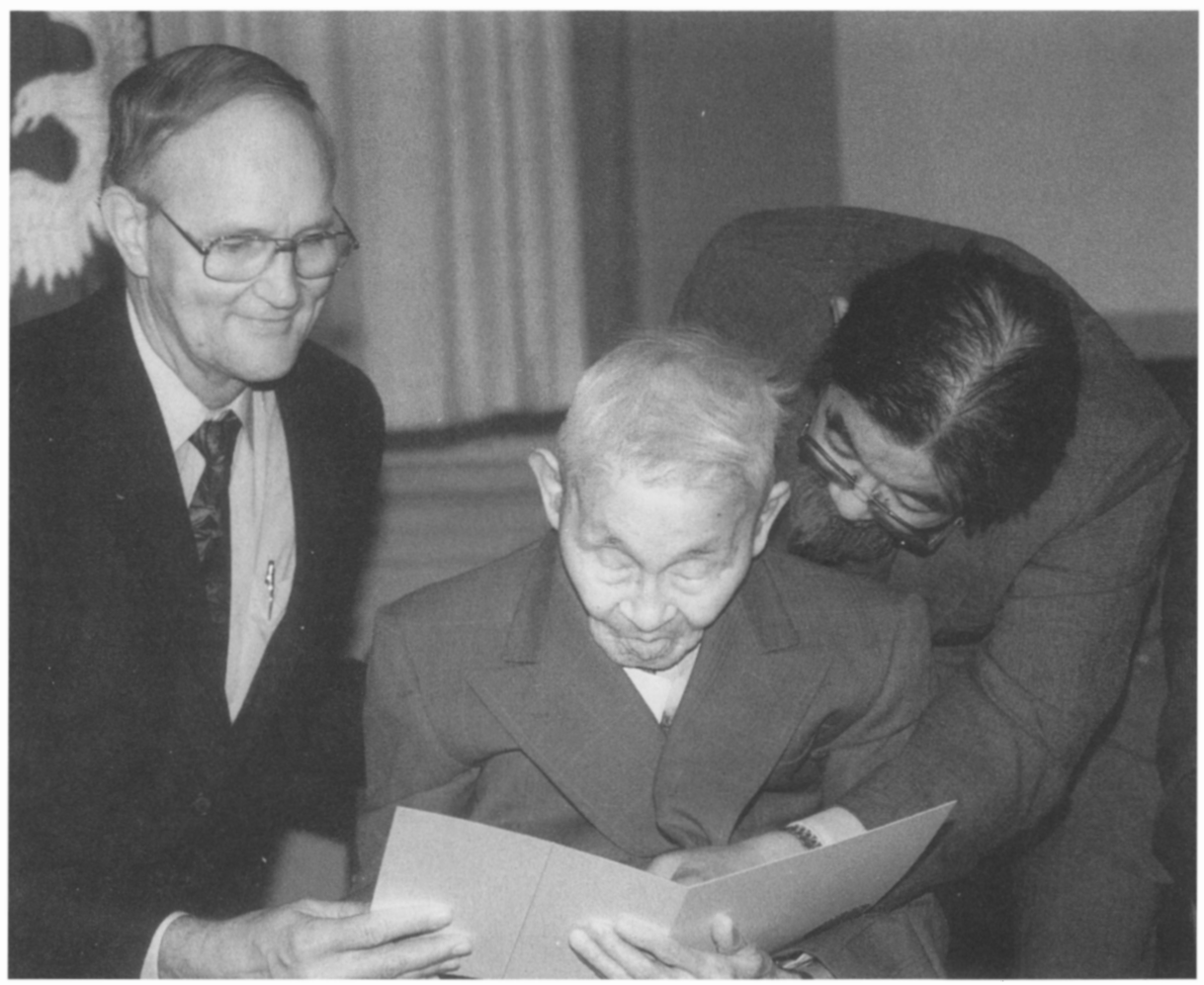

One of the oldest living survivors of Japanese American internment receives his letter of apology and redress check. Photo by Akio Yanagihara. 


\section{Breaking the Silence}

\section{REDRESS AND JAPANESE AMERICAN ETHNICITY}

\section{Yasuko I. Takezawa}

Cornell University Press

Ithaca and London 


\section{Copyright @ 1995 by Cornell University}

All rights reserved. Except for brief quotations in a review, this book, or parts thereof, must not be reproduced in any form without permission in writing from the publisher. For information address Cornell University Press, Sage House, $\mathbf{5 1 2}^{12}$ East State Street, Ithaca, New York $14^{8} 5^{\circ}$.

First published 1995 by Cornell University Press.

First printing, Cornell Paperbacks, 1995

Second printing 1996

\section{Library of Congress Cataloging-in-Publication Data}

Takezawa, Yasuko I., 1957-

Breaking the silence : redress and Japanese American ethnicity/

Yasuko I. Takezawa.

p. cm. - (Anthropology of contemporary issues)

Includes bibliographical references and index.

ISBN o-8014-2985-4. - ISBN o-8014-8181-3

1. Japanese Americans-Washington (State)-Seattle-Ethnic

identity. 2. Seattle (Wash.)-Ethnic relations. I. Title.

II. Series.

F899.S49J38 1994

$3^{05} .895^{\prime} 6079777^{2}-\mathrm{dc} 20 \quad 94-29600$

\section{Printed in the United States of America}

(2) The paper in this book meets the minimum requirements of the American National Standard for Information Sciences-Permanence of Paper for Printed Library Materials, ANSI Z $39.48-1984$. 
To those who died,

their ordeal not acknowledged,

and

to future generations of

Japanese Americans 

Breaking the Silence

honored by our ancestors

is a lamentation;

not of battles lost or won,

but a remembrance of the lives of those

who have passed before us. . . .

Breaking the silence

is also a tribute to their perseverance. . . .

We do this,

not to rake up old coals,

but to see with new eyes:

the past

can no more be denied.

—Nikki Nojima Louis,

Breaking the Silence 
